\title{
Standard Definitions of Building Geometry for Energy Evaluation
}

\section{Technical Report} NREL/TP-550-38600

October 2005

M. Deru and P. Torcellini 


\section{Standard Definitions of Building Geometry for Energy Evaluation}

M. Deru and P. Torcellini

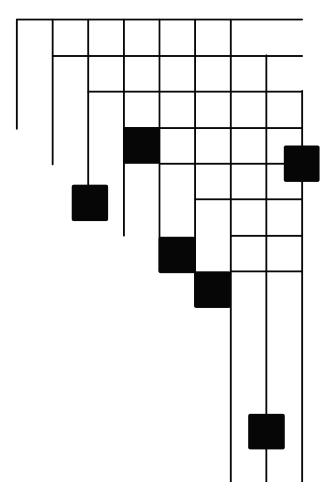

Prepared under Task No. BEC3.3002 


\section{NOTICE}

This report was prepared as an account of work sponsored by an agency of the United States government. Neither the United States government nor any agency thereof, nor any of their employees, makes any warranty, express or implied, or assumes any legal liability or responsibility for the accuracy, completeness, or usefulness of any information, apparatus, product, or process disclosed, or represents that its use would not infringe privately owned rights. Reference herein to any specific commercial product, process, or service by trade name, trademark, manufacturer, or otherwise does not necessarily constitute or imply its endorsement, recommendation, or favoring by the United States government or any agency thereof. The views and opinions of authors expressed herein do not necessarily state or reflect those of the United States government or any agency thereof.

Available electronically at http://www.osti.gov/bridge

Available for a processing fee to U.S. Department of Energy and its contractors, in paper, from:

U.S. Department of Energy

Office of Scientific and Technical Information

P.O. Box 62

Oak Ridge, TN 37831-0062

phone: 865.576 .8401

fax: 865.576 .5728

email: mailto:reports@adonis.osti.gov

Available for sale to the public, in paper, from:

U.S. Department of Commerce

National Technical Information Service

5285 Port Royal Road

Springfield, VA 22161

phone: 800.553 .6847

fax: 703.605.6900

email: orders@ntis.fedworld.gov

online ordering: http://www.ntis.gov/ordering.htm 
DISCLAIMER AGREEMENT

(“Agreement")

This document includes definitions, calculations and measurements of building geometry for use in energy performance analyses and is provided by the National Renewable Energy Laboratory ("NREL"), which is operated by the Midwest Research Institute ("MRI") for the U.S. Department of Energy ("DOE"). Access to and use of the information contained in this document shall impose the following obligations on the user, as set forth in this Agreement. The user is granted the right, without any fee or cost, to use, copy, modify, alter, enhance and distribute the information in this document for any purpose whatsoever, except commercial sales or other commercial purposes, provided that this entire notice appears in all copies of this document. Further, the user agrees to credit DOE/NREL/MRI in any publication that results from or includes any of the information contained in this document. The names DOE/NREL/MRI, however, may not be used in any advertising or publicity to endorse or promote any product or commercial entity unless prior specific written permission is obtained from the DOE/NREL/MRI. The user also understands that DOE/NREL/MRI is not obligated to provide the user with any support or assistance of any kind whatsoever with regard to the use of the information contained in this document or to provide the user with any updates, revisions or new versions of the information contained in this document.

YOU, THE USER, AGREE TO INDEMNIFY DOE/NREL/MRI, AND ITS SUBSIDIARIES, AFFILIATES, OFFICERS, AGENTS, AND EMPLOYEES AND HOLD THEM HARMLESS AGAINST ANY CLAIM OR DEMAND, INCLUDING REASONABLE ATTORNEYS' FEES, RELATED TO YOUR USE OF THE INFORMATION CONTAINED IN THIS DOCUMENT. THIS DOCUMENT, AND THE INFORMATION CONTAINED THEREIN ARE PROVIDED BY DOE/NREL/MRI "AS IS" AND ANY EXPRESS OR IMPLIED WARRANTIES, INCLUDING BUT NOT LIMITED TO, THE IMPLIED WARRANTIES OF MERCHANTABILITY AND FITNESS FOR A PARTICULAR PURPOSE ARE DISCLAIMED. IN NO EVENT SHALL DOE/NREL/MRI BE LIABLE FOR ANY SPECIAL, INDIRECT OR CONSEQUENTIAL DAMAGES OR ANY DAMAGES WHATSOEVER, INCLUDING BUT NOT LIMITED TO CLAIMS ASSOCIATED WITH AN ACTION IN CONTRACT, NEGLIGENCE OR OTHER TORTIOUS CLAIM THAT ARISES OUT OF OR IN CONNECTION WITH THE ACCESS, USE OR PERFORMANCE OF ANY OF THE INFORMATION CONTAINED IN THIS DOCUMENT. 


\section{Acknowledgments}

The authors would like to thank the following individuals for reviewing this document. David Hansen, Drury Crawley, and John Ryan of DOE, Ron Judkoff, Dennis Barley, Shanti Pless, and Otto Van Geet of NREL, and Jason Glazer of GARD Analytics. 


\section{Table of Contents}

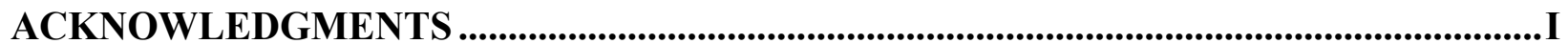

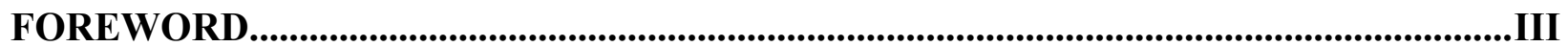

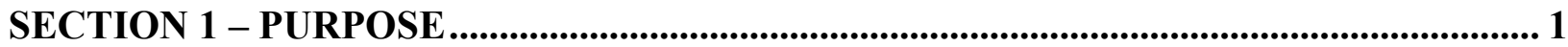

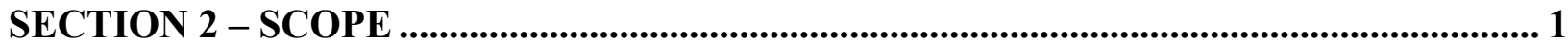

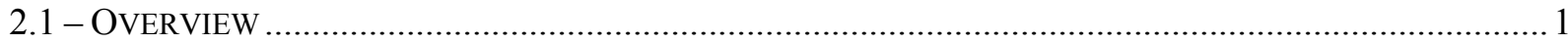

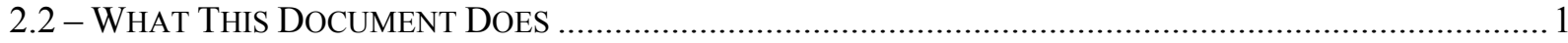

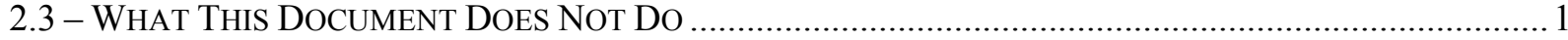

SECTION 3 - DEFINITIONS, ABBREVIATIONS, AND ACRONYMS .............................. 1

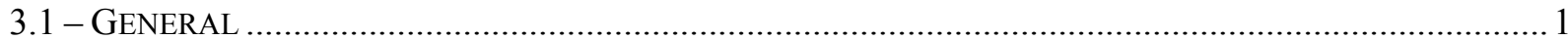

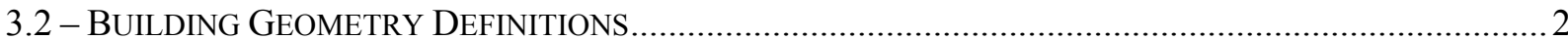

SECTION 4 - BUILDING GEOMETRY METRICS ......................................................... 4

REFERENCES

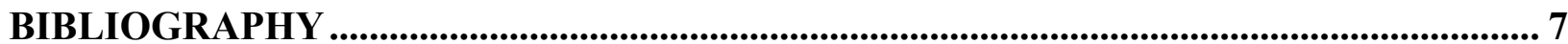




\section{Foreword}

Energy performance of buildings is measured and analyzed by many individuals for a variety of purposes. Interests in the energy performance range from global to regional, individual buildings, and finally individual systems. Users of energy performance data include policy makers, owners, designers, operators, building raters, and researchers. Many tools (or approaches) have been developed to analyze building energy performance in different ways, at different levels of effort and precision, and at different stages in the life of a building. With each of these tools, the building energy performance is quantified in a manner that fits the needs of the users. However, the methods and metrics from these tools are often inconsistent with each other. In addition, performance numbers are sometimes misrepresented or misused to predict energy savings beyond the accuracy of the numbers.

The Performance Metrics Project is a U.S. Department of Energy commercial buildings research activity whose goal is to standardize the measurement and characterization of building energy performance. The main products of this project are clearly defined energy performance metrics and standard procedures for determining the performance metrics. The intent of the project is to define common language and to create standards that produce consistent results independent of the user. Therefore, the terms and techniques are clearly defined with little room for interpretation. The products of this project focus on reporting absolute numbers and not on comparisons of energy performance. Benchmarks are included only where well-established values apply. However, benchmarking of results by others can be improved be using the clearly defined absolute metrics.

Numerous other documents outline procedures for analyzing building energy performance. Some of the existing procedures are very general in scope and tend to outline the stages of project planning, management, and execution; they do not encompass the level of detail necessary to standardize specific measurements among buildings. On the other hand, the existing procedures that do encompass the necessary level of detail are not sufficiently general to provide a standard basis of comparison among buildings. The Performance Metrics Project attempts to build on this body of work and resolve differences among the various approaches. The Performance Metrics Project has worked to address the following issues that have been problems with performance monitoring in the past:

- Standardization: Standard performance metrics provide a consistent basis for comparing energy performance among buildings.

- Versatility: The analysis is customized to the facility boundaries, energy configuration, analysis goals, and analysis budget that apply to a given project.

- Economy of Effort: The data collection is carefully matched to the goals of the analysis and the study questions, avoiding the common pitfalls of too little or too much data.

Each of the procedures in this series outlines a measurement protocol that leads to quantifying standard performance metrics. The primary users for whom these documents are intended are building energy analysts and technicians who design, install, and operate data acquisition systems, and who analyze and report building energy performance data. In addition, the Metrics Definitions in Section 4 of each procedure may be useful to others who interpret and apply such data. 


\section{Section 1 - Purpose}

This document provides standard definitions and metrics of building geometry to be used in energy performance analyses. Building geometry is an important input to the analysis process; however, there are no agreed-upon standard definitions of these terms specifically for use in energy analysis. Without standard definitions and metrics of building geometry, the analysis results may be questionable and meaningful comparisons are difficult.

These building geometry definitions and metrics are intended to be used for characterizing building geometry in measured energy analyses and for defining detailed energy simulation inputs. It is expected that the primary audience has a high-level of understanding of energy consumption in buildings and is familiar with building geometry. This audience includes building scientists and energy service professionals. This document may also be used as a reference to help other users have a better understanding of building geometry definitions.

\section{Section 2 - Scope}

\section{1 - Overview}

This document provides definitions of building features such as building envelope, ceiling, exterior wall, and fenestration as they are used in building energy analyses. This document also provides metrics, or standard definitions of measurable quantities, for building geometry such as volumes, gross floor areas, walls, and fenestration. The metrics can be used for characterizing building geometry, for calculating energy performance metrics, and for conducting energy simulations.

\section{2 - What This Document Does}

The definitions are intended to apply to commercial buildings; however, they could also pertain to other types of buildings on a case-by-case basis.

\section{3 - What This Document Does Not Do}

The definitions in this document are not intended for use in facility management or financial transactions. For those definitions, see the American Society for Testing and Materials (ASTM 2001) and the American National Standards Institute/Building Owners and Managers Association standards (BOMA 1996).

\section{Section 3 - Definitions, Abbreviations, and Acronyms}

\section{1 - General}

Terms, abbreviations, and acronyms defined in this section apply to this document. In addition, the names of metrics are defined in Section 4 and printed in bold type throughout this document. Terms, abbreviations, and acronyms not defined in either Section 3 or Section 4 are assumed to follow their most common definitions in the context in which they are used. 


\section{2 - Building Geometry Definitions}

Above-Grade Wall

An exterior wall or that portion of an exterior wall with the outside face not in contact with the ground.

\section{Below-Grade Wall}

An exterior wall or that portion of an exterior wall with the outside face in contact with the ground.

Building Envelope

The elements of a building that separate the interior spaces from the outside, such as walls, roofs, floors, doors, and fenestration.

Ceiling

Surfaces of a building that form the top surface of a space.

\section{Clerestory Windows}

Fenestration that exists in the upper portion of exterior walls or exterior walls that rise clear of the roof with the primary purpose of providing natural light to the interior.

\section{Conditioned Space}

An enclosed space within a building where there is intentional control of the space thermal conditions within defined limits using natural, electrical, or mechanical means. Spaces that do not have heating or cooling systems but rely on natural or mechanical flow of thermal energy from adjacent spaces to maintain thermal conditions within defined limits are considered conditioned spaces. Examples include restrooms that use exhaust fans to draw in conditioned air to maintain thermal conditions and atria that rely on natural convection flow to maintain thermal conditions. See definition for Unconditioned Space.

Conditioned spaces can be further classified by the following definitions:

Cooled Space: An enclosed space within a building that is intentionally cooled to maintain the thermal conditions below the maximum criteria.

Heated Space: An enclosed space within a building that is intentionally heated to maintain the thermal conditions above the minimum criteria.

Door

Operable openings in the building envelope that are for people or objects to pass through.

\section{Enclosed Space}

A volume of a building surrounded by solid surfaces such as walls, roofs, floors, fenestration, and doors where the total opening area to the outside can be reduced to less than $1 \%$ of the Gross Interior Floor Area of the space. Spaces that are temporarily enclosed such as patios enclosed with tenting are not considered Enclosed Spaces for annual building analysis. These spaces should be treated as exterior to the building. 


\section{Exterior Wall}

The solid portion that forms the sides of the building envelope, including opaque walls, doors, and fenestration areas. Walls form the portion of the building envelope that is not the roof or floor. They are usually near vertical surfaces, but this is not a requirement.

Fenestration

Building components that transmit light including windows, translucent panels, clerestory windows, skylights, glazed portions of doors, and glass block walls. ${ }^{1}$

Floor

Surfaces of a building that are horizontal or near horizontal and form the bottom surface of a space.

\section{Lighted Space}

An enclosed space within a building with electric or other lighting, excluding spaces that are lit only with natural daylight or only with light from another space.

Metric

A standard definition of a measurable quantity.

Roof

The upper portion of a building envelope, including opaque and fenestration areas, that is horizontal or tilted at an angle of less than $60^{\circ}$ from the horizontal. ${ }^{2}$

Skylight

Fenestration that is located in a roof.

Thermal Conditions

The characteristics of a space that affect a person's heat transfer to the space, which include the air temperature, radiant temperature, air movement, and air moisture content.

UA Product

The product of the overall thermal conductance and the area of an element, including the thermal conductance of the air film on both sides of the element.

Unconditioned Space

An enclosed space within a building that does not meet the requirements of a conditioned space. Spaces that have no control over thermal conditions but intentionally or unintentionally receive thermal energy from adjacent spaces are considered unconditioned spaces (such as an attached garage on a house or a vestibule with no thermal comfort criteria). Spaces that are ventilated only to maintain air quality are considered unconditioned spaces (such as a parking garage with no thermal comfort criteria).

\footnotetext{
${ }^{1}$ Modified from ASHRAE 90.1-2001.

${ }^{2}$ See note 1 .
} 


\section{Section 4 - Building Geometry Metrics}

The metrics defined below can be determined from measurements of the actual building or from the building drawings. Electronic versions of the drawings are the easiest to use; however, the drawings must be verified against the actual building for accuracy. Adding or modifying building components is common during the construction phase or during a building retrofit. Conducting a walk through of the building, carefully noting the geometry features with a few spot measurements of the key features, is sufficient to verify the drawings. The building manager may have an up-to-date set of as-built drawings on file.

Very little attention is usually given to the accuracy of area measurements; however, the results can vary greatly depending on the methods used and the care taken in their measurement. Discrepancies can occur due to interpretations of definitions, inaccurate drawings, and mistakes in measurement. Determining the uncertainty in geometry measurements is difficult, but it can be minimized by adherence to the metric definitions and to an accurate representation of the building. An uncertainty estimation will determine how accurate the measurements must be to be within the desired accuracy of the project.

All area geometry metrics should be reported in units of square feet $\left(\mathrm{ft}^{2}\right)$ or square meters $\left(\mathrm{m}^{2}\right)$, and volume geometry metrics should be reported in units of cubic feet $\left(\mathrm{ft}^{3}\right)$ or cubic meters $\left(\mathrm{m}^{3}\right)$.

\section{Building Conditioned Volume}

Volume inside the building envelope of the conditioned spaces. This metric can be calculated as the volume of the building if every space is conditioned or on a floor-by-floor basis. For spaces with vertical walls and horizontal ceilings and floors, this is calculated as the Gross Conditioned Floor Area times the height from the top surface of the finished floor to the top surface of the finished floor separating levels of the building or to the inside surface of the roof for the top floor. The volume of spaces that have nonvertical walls or nonhorizontal ceilings of floors should be calculated separately to properly account for the non-square geometry. This metric does include the volume of floor or ceiling return air plenums.

\section{Door Area}

The area of door including the door frame.

\section{Fenestration to Floor Area Ratio}

The ratio of the Wall Fenestration Area and the Gross Interior Floor Area.

Calculated as: $\frac{\text { WallFenestration Area }}{\text { Gross Interior Floor Area }}$

\section{Fenestration to Wall Area Ratio}

Percent of the above-grade wall area that is covered by fenestration, calculated as the ratio of the Wall Fenestration Area and the Gross Above-Grade Wall Area.

Calculated as: $\frac{\text { Wall Fenestration Area }}{\text { Gross AboveGradeWall Area }}$ 


\section{Gross Above-Grade Wall Area}

The area of the above-grade exterior walls, measured on the exterior face of the walls from the exterior finished grade (i.e., the ground surface) to the bottom of the roof, including the area of fenestration in the wall.

\section{Gross Building Floor Area}

Total floor area of a building's enclosed spaces, measured from the outside face of exterior walls or from the centerline of walls of adjoining buildings. This metric is measured on a floor-byfloor basis and includes the area of interior walls, basements, mezzanines, penthouses, equipment rooms, and interior parking. Vertical penetrations on each floor (such as elevator shafts and stairwells) should be included based on the floor area it penetrates. It does not include open covered walkways, courtyards with no roof, balconies, and canopies. Structures that extend beyond the plane of the outside face of the exterior wall such as cornices, pilasters, buttresses, and overhangs are not included. ${ }^{3,4}$

\section{Gross Building Volume}

Volume enclosed by the entire building envelope, including interior parking garages, attics, crawl spaces, and penthouses. This metric is measured from the outside surface of exterior walls, floors, and roofs. It does not include open covered walkways, courtyards with no roof, balconies, and canopies. Structures that extend beyond the plane of the outside face of the exterior wall such as cornices, pilasters, buttresses, and overhangs are not included.

\section{Gross Conditioned Floor Area}

Total interior floor area of a building's conditioned spaces, measured from the inside surface of the exterior walls or from the interior surface of walls of adjoining buildings. The areas of interior walls, columns, and pillars are included in this measurement. This metric is measured on a floor-by-floor basis and consists of all conditioned spaces, including the area of interior walls, basements, mezzanines, penthouses, equipment rooms, and vertical penetrations on each floor (such as elevator shafts, and stairwells). It does not include interior parking garages, open covered walkways, courtyards with no roof, balconies, and canopies. It is equal to the Gross Interior Floor Area minus the floor area of unconditioned spaces.

\section{Gross Interior Floor Area}

Total interior floor area of a building's spaces, measured from the inside surface of the exterior walls or from the interior surface of walls in common with adjoining buildings. The area of interior columns and pillars is included in this measurement. This metric is measured on a floorby-floor basis and consists of all enclosed spaces, including the area of interior walls, basements, mezzanines, penthouses, equipment rooms, vertical penetrations on each floor (such as elevator shafts, and stairwells), and interior parking. It does not include open covered walkways, courtyards with no roof, balconies, and canopies.

\section{Gross Roof Area}

The area of the roof, measured from the exterior faces of exterior walls or the centerline of walls of adjacent buildings including the area of fenestration in the roof.

\footnotetext{
${ }^{3}$ See note 1 .

${ }^{4}$ Modified from ASTM 1836-01 (ASTM 2001).
} 


\section{Lighted Floor Area}

Floor area of spaces with installed lighting, measured from the interior face of exterior walls of the space and including the dimensions of walls interior to the space.

\section{Skylight Fenestration Area}

Area of the fenestration and frame in roofs.

\section{Skylight to Floor Area Ratio}

The ratio of the Skylight Fenestration Area and the Gross Interior Floor Area.

Calculated as: $\frac{\text { Skylight Fenestration Area }}{\text { Gross Interior Floor Area }}$

\section{Total Fenestration Area}

Total area of the fenestration and fenestration frame in exterior walls and roofs. For doors with glazing area covering less than $50 \%$ of the area, the fenestration area is the glazing area only. For doors with glazing area more than $50 \%$ of the area, the fenestration area is the door and door frame.

\section{Wall Fenestration Area}

Area of the fenestration and fenestration frame in exterior walls. For doors with glazing area covering less than $50 \%$ of the area, the fenestration area is the glazing area only. For doors with glazing area more than $50 \%$ of the area, the fenestration area is the door and door frame. Clerestory windows are included in this metric, but skylights are not included. 


\section{References}

ASHRAE (2004). Energy Standard for Buildings Except Low-Rise Residential Buildings. ANSI/ASHRAE/IESNA Standard 90.1-2004. Atlanta, GA: American Society of Heating, Refrigerating, and Air-Conditioning Engineers.

ASTM (2001). Standard Classification for Building Floor Area Measurements for Facility Management. E 1836-01. West Conshohocken, PA: American Society for Testing and Materials.

BOMA (1996). Standard Method for Measuring Floor Area in Office Buildings. ANSI/BOMA Z65.11996. Washington, D.C.: Building Owners and Managers Association International.

\section{Bibliography}

ASHRAE (1995). Energy Conservation in Existing Buildings. ANSI/ASHRAE/IESNA Standard 1001995. Atlanta, GA: American Society of Heating, Refrigerating, and Air-Conditioning Engineers.

ASHRAE (1999). Standard Methods of Measuring and Expressing Building Energy Performance. ANSI/ASHRAE Standard 105-1984 (RA 99). Atlanta, GA: American Society of Heating, Refrigerating, and Air-Conditioning Engineers.

EIA (2003). Energy Information Administration Web page. Available at http://www.eia.doe.gov/ (Accessed May 12, 2003).

MacDonald, J. M.; Sharp, T.R.; Gettings, M.B. (September 1989). A Protocol for Monitoring Energy Efficiency Improvements in Commercial and Related Buildings. ORNL/CON-291. DE89 012800. Oak Ridge, TN: Oak Ridge National Laboratory (ORNL).

DOE (2002). "Report Guidance for FY 2002 Annual Report on Federal Government Energy Management and Conservation Programs." U.S. Department of Energy Memorandum. Federal Energy Management Program. Available at http://www.eere.energy.gov/femp/aboutfemp/doc/02guide.doc. (Accessed May 13, 2003).

EPA (November 2001). Professional Engineer's Guide to the Energy Star ${ }^{\circledR}$ Label for Buildings. Washington, DC: U.S. Environmental Protection Agency. Draft EPA 430-F-01-xxx.

ICC (2003). International Building Code. International Code Council, Inc., Country Club Hills, IL. 


\section{REPORT DOCUMENTATION PAGE}

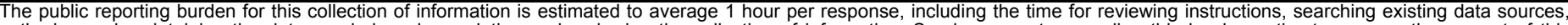

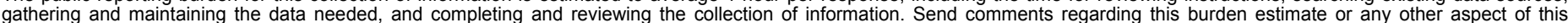

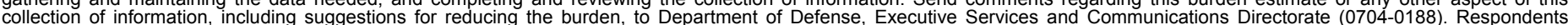

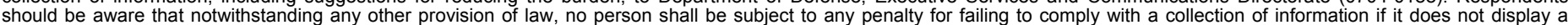

currently valid OMB control numbe

PLEASE DO NOT RETURN YOUR FORM TO THE ABOVE ORGANIZATION.

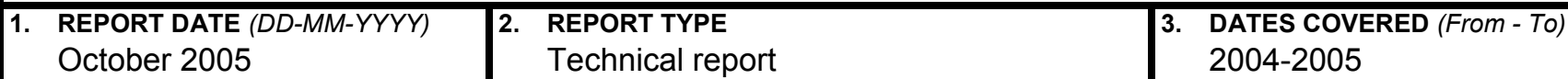

4. TITLE AND SUBTITLE

Standard Definitions of Building Geometry for Energy Evaluation 5a. CONTRACT NUMBER

DE-AC36-99-G010337

5b. GRANT NUMBER

5c. PROGRAM ELEMENT NUMBER

5d. PROJECT NUMBER

NREL/TP-550-38600

5e. TASK NUMBER

BEC3.3002

5f. WORK UNIT NUMBER
7. PERFORMING ORGANIZATION NAME(S) AND ADDRESS(ES)

National Renewable Energy Laboratory

1617 Cole Blvd.

Golden, CO 80401-3393

9. SPONSORING/MONITORING AGENCY NAME(S) AND ADDRESS(ES)
8. PERFORMING ORGANIZATION REPORT NUMBER

NREL/TP-550-38600
10. SPONSOR/MONITOR'S ACRONYM(S) NREL

11. SPONSORING/MONITORING AGENCY REPORT NUMBER

12. DISTRIBUTION AVAILABILITY STATEMENT

National Technical Information Service

U.S. Department of Commerce

5285 Port Royal Road

Springfield, VA 22161

13. SUPPLEMENTARY NOTES

14. ABSTRACT (Maximum 200 Words)

This document provides definitions and metrics of building geometry for use in building energy evaluation. Building geometry is an important input in the analysis process, yet there are no agreed-upon standard definitions of these terms for use in energy analysis. The metrics can be used for characterizing building geometry, for calculating energy performance metrics, and for conducting energy simulations.

\section{SUBJECT TERMS}

performance metrics; building energy analysis; commercial buildings; building energy performance; energy performance; energy performance benchmarks; energy analysis procedure; high performance buildings; building geometry; geometry definitions for buildings; energy evaluation and geometry.

\begin{tabular}{|l|l|l|l|l|}
\hline \multicolumn{2}{|l|}{ 16. SECURITY CLASSIFICATION OF: } & 17. LIMITATION \\
OF ABSTRACT & $\begin{array}{c}\text { 18. NUMBER } \\
\text { OF PAGES }\end{array}$ \\
\hline $\begin{array}{l}\text { a. REPORT } \\
\text { Unclassified }\end{array}$ & $\begin{array}{c}\text { b. ABSTRACT } \\
\text { Unclassified }\end{array}$ & $\begin{array}{l}\text { c. THIS PAGE } \\
\text { Unclassified }\end{array}$ & UL & \\
\end{tabular}

19a. NAME OF RESPONSIBLE PERSON

19b. TELEPHONE NUMBER (Include area code) 